Linguistik Terapan 16 (1) (2019): 281-290

Jurnal Linguistik Terapan Pascasarjana

Available online

http://jurnal.unimed.ac.id/2019/index.php/JLT-Unimed

\title{
THE SHIFT OF THEMES AND RHEMES IN THE TRANSLATION OF ENGLISH POLITICAL TEXTS INTO INDONESIAN
}

\author{
Widya Astuti
}

Rahmad Husein

Syahron Lubis

English Applied Linguistics Program

Postgraduate Program - Universitas Negeri Medan

Diterima Desember 2018; Disetujui Februari 2019; Dipublikasikan April 2019

\section{ABSTRACT}

This study was conducted to describe the shift of themes and rhemes in The Translation of English Political Text into Indonesian. In this research, descriptive qualitative design is applied by the researcher in order to answer the questions. The data were taken from English and Indonesia political news texts of Waspada. The technique used was interactive model by Miles, Huberman and Saldana (2014). This study found some enrichment with variation of theme and information structure of thematic and rhematic in English - Indonesia Waspada political texts. Based on analyzing data, the findings of this study are formulated : (1) There are some ways in which shifts applied in the thematic and rhematic in English - Indonesian translation of Waspada political texts there are such as : the SL which is differently translated into TL considering the grammatical pattern of both language and the unit of word constructing the theme and rheme and (2) There are some reasons for applying shifts in the thematic and rhematic shift in English - Indonesian translation of Waspada political texts such as different language system and grammatical structure from both English and Indonesia.

Keywords: Translation Shifts, Theme, Rheme, Political, Text

How to Cite: Astuti, Widya (2019)

The Shifts of Themes and Rhemes in The Translation of English Political Texts into indonesian.Jurnal Linguistik Terapan Pascasarjana Unimed.16 (1): 281-290.

*Corresponding author:

ISSN 0216-5139

E-mail:Widyaastuti236@gmail.com 


\section{INTRODUCTION}

Hasan (2015); Vahedifar and Koohas (2015) state that thematic structure is an important and interesting discussion in Translation study since translation is more than the mere replacement of the ST materials into the TT, theme and rheme contributed to the notion of translation.Sharndama and Panamah (2013); Kalantari(2013); and Wang (2014) state that the success of delivering message depend on the large extend on the packaging and structuring the message. Moreover Hasan (2015); Vahedifar and Koohas (2015); Kadhim and Syaibani (2013); state that translators will pass some challenges in keeping the thematic, it is not always possible to maintain the same word order to keep the same theme and rheme structure. Wang (2014) adds that there are cases where the T-R structures have been shifted to R-T and moreover the translator must make sure that the thematic patterns contribute to the cohesion and coherence of the target language text and does not distort the meaning of the original text.Since thematic structure in one of the important component in Translation, The translators should consider the transfer of the thematic structure in translation after convening the message. (Vahedifar and Koohas (2015);Sharndama and Panamah (2013); Habazarirad and Moghimizade(2017). Moreover Bo Wang (2014); Sun (2014); Sariasih and Zaim (2015); Triastika (2017) add that the translator should get mastery over the grammar and structure of both source and target languages, particularly in terms of thematic structure.

Seeing how important thematic structure to form the elements in delivering a message that is worth. The political news of Waspada newspaper is chosen. The English news is as the Source Text while Indonesia news is as the Target Text. The researcher in the present study attempts to contrast two languages' thematic structures (English and Indonesia) in Waspada newspaper to find out the similarities and differences between them.

Here, the researcher found that the different information contained in both English and Indonesian Political News of Waspada influenced by the structure of theme and rheme constructed. The English news version (SL) is taken from BBC and it is published on November, $8^{\text {th }} 2017$ There are unacceptable forms according to Indonesia (TL). Based on the observation, the preliminary data showed that:

a. (SL) the arrest of dozens of Saudi royal figure, minister andbusinessman is just the start of an anti-corruption drive, the attorney general says.

(TL) Gerakan antikorupsi di Arab Saudi tidak berakhir dengan penangkapan 11 Pangeran, empat menteri and puluhan mantan menteri. 
b. (SL) The idea of dozens of familiar pillars of establishment all being publicly humiliatingly removed from office and detained, albeit in great comport, would have been unthinkable just three years ago.

(TL) Fakta bahwa ada sejumlah anggota keluarga kerajaan ditahan dan dipermalukan didepan umumtidak pernah terfikirkan tiga tahun lalu.

c. (SL) "Some of those they are harshly treating have been "milking" their country for years!" Mr. Trump Added.

(TL) "beberapa diantara merekatelah memerah Negara mereka selama bertahuntahun!" Sambungnya.

Based on the data above it is found that: (1) There is a shift of theme and rheme occurred which Theme in SL such as: in (a) "the arrest of dozens of Saudi royal figure, minister andbusinessman", while Theme in TL is "Gerakan anti korupsi di Arab Saudi". It is called as structure Shift which the Theme in SL becomes the Rheme in TL while Rheme in SL becomes Theme in TL. In (2) There is different information which is mentioned in Both SL and TL. In SL stated that businessman is also arrested while it is not stated in TL or in other word, TL content decreased the information. Moreover there is no stated in SL that the number of Saudi royal figure is 11 such the TL stated it or in other word, The TL contained additional information related to the news which is not stated in that news. In (3) keeping the same structure of theme and rheme in both SL and TL in this case, contribute to unacceptability of TL such as in (b) and (c) both SL and TL has the same structure in theme and rheme. The italic is Theme and The underlined one is rheme. Unfortunately idea flow in that TL messages sounds rare and weird in Indonesian. Moreover in (3), the rank shift happened, which the clause in SL is changed into Phrase in TL "Mr. Trump Added" translated to "sambungnya".

. Considering the researcher's preliminary data, it is needed to conduct more research toward English and Indonesia political news of Waspada newspaper. The problems of the study are formulated as the following.

1. How are thematic and rhematic shifts applied in translation of English political texts into Indonesian?

2. Why are the shifts applied in translation of English political texts into Indonesian?

\section{RESEARCH METHOD}

In this research, descriptive qualitative design was applied by the researcher in order to answer thequestions. The data of this study were the clauses of English- Indonesia Political 
texts of Waspada.The English news which is Waspada translated into Indonesian and published were taken from Al-Jazeera, Gulf News, BBC, Daily Mail, Press Trust of India and Reuters. There are five political texts in the form of English as the SL and Indonesia as TL. This choice was aimed to make the research efficient and practical. The unit of analysis is all the clauses of both English and Indonesia Political Texts of Waspada.

\section{RESEARCH FINDINGS}

After analysing the data, the findings were formulated below:

\section{The ways of Thematic and Rhematic shift used in English - Indonesia translation of Waspada's political texts}

\section{Structure Shift}

Structure shift was applied because there is a grammatical shift applied as the demand of language structure of SL and TL. Moreover it is also relate to the choice of the translation technique by the translator. For example, it can be seen on data number 34

SL : fourteen bullet were found

TL : total ada 14 peluru yang ditemukan

Based on the example, it can be seen that the sentence in SL "fourteen bullet were found", the theme is "fourteen bullet", and the rheme is "were found", while in TL, the sentence is translated become "total ada 14 peluru yang ditemukan". it can be identified "total" as the theme in TL and "ada 14 peluru ditemukan" as the rheme in TL. It can be seen that the entity which is mentioned as the theme in SL is delivered in TL Rheme.

\section{Unit Shift}

Unit shifts were when the unit of theme in SL item is translated differently in the form of TL item. The example :

SL : both are carrying backpacks and have on dark jacket and helmets.."

TL : saat bersaksi, dua tersangka disebut membawa tas ransel dan memakai jaket serta helm berwarna gelap.

Based on the data above, it can be seen that the Theme in SL was "both" which was identified as vocative - interpersonal theme while the theme in TL was "saat beraksi, dua tersangka" which was identified as conjunction interpersonal -topical theme then there is a unit / rank shift occurred. 


\section{Class Shift}

Class shift item is translated with a TL item which belongs to a different class, such as Noun which is changed into verb, Adjective to Noun etc. For example:

SL : Palestinian sources said that the settlers' instruction are taking place amidst provocative tours in the mosque

TL : dilansir digulf times, jumat (20/4), sumber sumber palestina mengatakan bahwa kekacawan atau gangguan yang dilakukan para pemukim itu terjadi ditengah tur provokatif di masjid tersebut.

It can be seen that theme in SL is "Palestinian sources" which is identified as noun, topical theme while in TL, it was translated into "dilansir digulf times, jumat (20/4)" which is classified as the phrase and it consisted of verb, noun and adverb then identified as interpersonal theme .

\section{Markedness Shift}

Markedness shift occurred when the translation equivalent of a source language in this case, the theme was indicated as marked theme while it was translated differently in the target language became unmarked theme and vise verse.

For instances :

SL : in 2016, Hamas blamed mossad for the killing of a Tunisian national.

TL : kelompok hamas yang menguasai Gaza telah mengklaim Batsh sebagai anggotanya.

It can be seen that theme in SL "in 2016" was identified as Unmarked Topical theme while in TL, the theme was "kelompok hamas yang menguasai gaza" it was identified as textual-interpersonal theme which is identified as Marked theme.

\section{The Reasons for Thematic and Rhematic Shift were used in English - Indonesia}

\section{Translation of Waspada's Political Texts.}

There is a relationship while people delivering the message or idea toward the structure of thematic and rhematic. When the messages are delivered the information in the form of clause tells us about where the clause is coming and where it is going. In the language, English or Indonesia, the clause consists of theme and rheme. In here there are two reasons in constructing the shift of thematic and rhematic in Translation of English Indonesian political texts. 
The first, When SL and TL have different language system, so the shift used automatically and the translator has no option but to undergo those shift. This shift commonly applied in the form of structure shift of shift type thematic and rhematic.

Structure shiftswere applied because there were grammatical shifts applied as the demand of language structure of SL and TL. Moreover it is also relate with the choice of the translation techniques by the translator.

For instance:

SL : Monday toward populated areas in the southern Saudi province of Najran TL : Missil ditargetkan menyerang area padat penduduk di Provinsi Najran, Saudi

From that example, the underlined words belong to theme. It can be seen that since the SL only appeared in the form of theme with no rheme accompanied because the SL which is translated is the phrase form into the sentences in TL.

The second, when the total unit of the theme component in SL and TL was different, it is done by the researcher in order to add more information or focus, decrease information and change them by putting in the rheme. It can be seen in the following example

TL : Organizations of the alleged Temple called on their supporters through their media and social networking sites to participate extensively in Al-Aqsa's incursions today on the occasion of the so-called 'Independence of Israel'

SL : organisasi itu menyerukan pendukung mereka melalui media dan situs jejaring sosial untuk berpartisipasi secara luas dalam serangan ke Al-Aqsa. Mereka menyebut kesempatan tersebut sebagai 'Kemerdekaan Israel'.

This kind of reason commonly occurred in the one of the shift type which is then called unit shift. In translation process when the condition of the changing unit of SL and TL happen, it consider Interpersonal, Topical and textual. and For interpersonal, It covers finite, question word, vocative and adjunct, while topical cover participant, circumstance and process and textual covers conjunctions, relatives, conjunctivas and continuities.

Based on the analysis of thematic and rhematic of Waspada political text in English Indonesia translation, it is revealed that the unmarked them from topical theme is the most dominant theme in both English and Indonesia political text of Waspada and the most dominant shift is Structure shift.

\section{DISCUSSION}

Based on the finding above, this part discussing the finding in the detail. the First is The four types of thematic and rhematic of Translation shift found in Waspada English Political Texts. 
The second, Theways of thematic and rhematic of Translation shift found in Waspada English Political Text and the third Thereasons. of thematic and rhematic of Translation shift found in Waspada English Political Text.

For the first finding, The first is the four types of thematic and rhematic of translation shift found in Waspada political texts into Indonesian. the first it can be seen that structure shifts were applied by the translator. In case data 4, SL : Monday toward populated areas in the southern Saudi province of Najran and TL : Misil ditargetkan menyerang area padat penduduk di Provinsi Najran, Saudi, the form of SL consisted theme only which is "Monday toward populated areas in the southern Saudi province of Najran", while in TL, the form is translated differently "Misil" as the theme and "ditargetkan menyerang area padat penduduk di Provinsi Najran, Saudi" as the rheme. The second, in the data 27, SL : Malaysia releases images of suspects in murder of Palestinian while TL : "Sketsa Pembunuh Ilmuwan Palestina dirilis". It can be seen that the theme in SL was "Malaysia" and TL was "Sketsa Pembunuh Ilmuwan Palestina" while the rheme in SL was "releases images of suspects in murder of Palestinian" and TL was "dirilis". The structure shift was applied since the idea of rheme in SL is translated in TL theme. In other words, data 4 showed structure shift when the SL consisted theme only and it was translated into clause that containing theme and rheme. While data 27 showed the structure shift when the idea in SL rheme is translated in TL theme.

While in unit shifts were when the unit of theme in SL item is translated differently in the form of TL item. In Data 11, SL : "And it was impossible to manufacture them locally "and the TL : “dia menambahkan, militernya tidak memiliki peralatan tempur semacam itu". It can be seen that the Theme in SL was And it which was identified as conjunction textualtopical theme while the theme in TL was "dia" which was identified as topical theme then there is a unit / rank shift occurred.

In Data 12, SL : "Iran backs the Houthis, who seized Sanaa in 2014, prompting a Saudiled military coalition to intervene against the rebels the following year" and the TL : Sebelumnya, pada Rabu (11/4), pasukan pertahanan udaramenghalau tiga rudal yang ditembakkan ke Riyadh dan kota lainnya. . It can be seen that the Theme in SL was "Iran" which was identified as simple topical theme while the theme in TL was "Sebelumnya, pada Rabu (11/4), pasukan pertahanan udara Arab Saudi" which was identified as conjunction textual topical theme then there is a unit / rank shift occurred.

In Data 14, SL : "Coalition-backed forceskilled two al Qaeda militants in Yemen in a raid in the southern province of Abyan on Wednesday, the Saudi government media office said" 
and the TL: "Pasukan yang didukung koalisi pimpinamenewaskan dua gerilyawan AlQaeda di Yaman dalam serangan di Provinsi Abyan, Irak selatann Arab Saudi”. It can be seen that the Theme in SL was "Coalition-backed forces" topical theme while the theme in TL was "Pasukan yang didukung koalisi pimpinan Arab Saudi" which was identified as topical vocative theme then there is a unit / rank shift occurred.

While in class shift, item is translated with a TL item which belongs to a different class, such as Noun which is changed into verb, Adjective to Noun etc. It can be seenin Data 1 SL :" Houthislaunch missile after Saudi-led coalition warns of 'painful' response;attack thwarted" and in was translated in TL : "LagiSaudi Lumpuhkan Rudal Houthi". It can be seen that theme in SL "Houtis" is Topical theme which means categorized as noun while in TL, it was translated in to "lagi" and identified as conjunction which is called conjunction textual theme.

While Markedness shifts were applied in constructing the theme in source language and target language. . It can be seenin Data 7 the theme of SL :"Saudi forces" and the theme in TL : "Sebelumnya,". It can be seen that theme in SL was identified as Unmarked Topical theme while in TL, it was conjunction textual theme which is identified as Marked theme.

In Data 12 the theme of SL :"Iran" and the theme in TL : "Sebelumnya, pada Rabu (11/4),". It can be seen that theme in SL was identified as Unmarked Topical theme while in TL, it was conjunction textual theme which is identified as Marked theme.

\section{CONCLUSION}

1. There are some ways in which shift happen in the thematic and rhematic of waspada's political text. The SL which is differently translated into TL considering the grammatical pattern of both language and the unit of word constructing the theme and rheme.

2. There are some reasons for applying shifts in the thematic and rhematic shifts in Waspada political texts such as different language system and grammatical structure from both English and Indonesia. 


\section{References}

Andrianie Dewi, Eva Tuckyta Sari Sujatna and Heriyanto (2014). Transposition of Theme and Rheme in "Habibie \&Ainun” and "Habibie \& Ainun The Power of Love":A Translation Study of Indonesian to English. International Journal of Language Learning and Applied Linguistics World (IJLLALW). Volume 5 (4), April 2014; 22-36

Catford, J.C. (1965) A linguistics Theory of Translation. London : OxfordUniversity Press

Damayanti, Yuanita (2016). Theme Equivalence and Theme Shift Found in Indonesian-English Translation of Thesis Abstracts. Journal of Translation. Vol.1.

Halliday, M.A.K. (1994). An Introduction to Functional Grammar (2 ed.). London: Edward Arnold

Halliday, M.A.K. (1994). An Introduction to functional grammar (2 ed.). London: Edward Arnold Halliday,

M.A.K., \& Matthiesssen.Ch. (2004), An Introduction to Functional Grammar (3 ed.). London: Edward Arnold

Hasan (2015). Thematic Structure in The Arabic Translations of Edgar Allan Poe's The Black cat, The TellTale Heart and Virginia Woolf's a Haunted House. International Journal of Language and Linguistics. International Journal of Language and Linguistics. Vol.3(3): 132-139

Hatim and Munday (2004). Translation and Advance Resourced Book. New York

Herman. Shift in Translation from English into Indonesia on Narrative Text. International Journal of European Studies. Vol. 1, No. 3, 2017, pp. 72-77. doi: 10.11648/j.ijes.20170103.11

Kang, Junying (2016) A Functional Approach to the Status of Theme and Textual Development Theory and Practice in Language Studies, Vol. 6, No. 5

Kadhim, Kais A, Ahaker Al-Ahaibani, Ghayth k. (3013) Analysis of Thematic Structure in English Arabic News Texts. Topics in Linguistics - Issue 12 - December 2013

Kalantari, afsaneh (2013). Assessment of Marked Thematic Structures in The Two persian translations of "the sound and the fury". Journal of Translation. vol.4. No. 26-2013

Larson, Mildred L. (1984) Meaning-based Translation : A guide to Cross - Langauge Equivalence. Lanham and New York : University Press of America

Lincoln, Y.S and Guba, E.G (1985). Naturalistics Inquiry. California : Sage

Miles, M.B and Huberman, A.M (2014). Qualitative Data Analysis. California : Sage.

Mardani Tooba (2016) Thematic Structure: A Study on English and Persian. Journal of Translation. Vol.2. No.2-2016

M. Manfredi. (2014)Translating Text and Context: Translation Studies and Systemic Functional Linguistics. Vol. II From Theory to Practice. Bologna: Centro di Studi Linguistico-Culturali (CeSLiC).

Newmark, Peter (1981). Approach to The Translation. London : Oxford Press.

Nida, E. A.(1975).Language Structure and Translation. California. Standford

University Press

Rashidifar , Ahmad Amin and Seyed Foad Ebrahimi (2015). The Status of Theme in Political Interviews: A Case of Nativeand Nonnative Speakers. Journal of Applied Linguistics and Language Research. Volume 2, Issue 1. 
Rusdi Noor Rosa, T. Silvana Sinar, Zubaidah Ibrahim-Bell, Eddy Setia. (2017).Metafunctional Shifts in the Translation of Student and Professional Translators. International Journal of Sciences: Basic and Applied Research (IJSBAR) (2017) Volume 35, No 2, pp 85-101

Sarcinelli, U.1998.Politikvermittlung und Demokratie in der Mediengesellschaft [Politics and Democracy Seen through the Media].Bonn: BpB.

Sharndama (2013) Thematic Structure and Progression in Selected Business News Reports of Two Nigerian Newspapers: Implications for Professional Writing. Journal of Linguistics. Vol. 42, pg 1076-1136

Sun, Qiang (2014). A Contrastive Analysis of Thematic Progression Patterns in the Abstracts of English and Chinese Academic Journal Articles. The Asian ESP Journal. Volume 13, Issue 1

Szabó, Márton. (2003). A diszkurzív politikatudomány alapjai [The Bases of Discursive Politics]. Budapest: L'Harmattan Kiadó.

Szabó, Miklós. (2000). Szó szerint: a jog és a nyelv interferenciájáról [Word by Word: On the Interferences of Language and Law]. In Szabó M. and Varga Cs. (eds.), Jog és nyelv [Law and Language], 198.Budapest: PPKE.

Szabó, Miklós. (2001). Játsszunk! [Let’s play!]. In Szabó, Miklós (ed.), Ius humanum. Ember alkotta jog. Mühelytanulmányok [Ius Humanum. Law Made by Man. Studies], 41-73.Miskolc: Bíbor

Triastika, Herlyn (2017) Textual Equivalence in The Translation of English Texts Into Indonesian. International Journal of Language Education and Culture Review, Vol.3 (1) June 2017, $77-83$.

Vahedifar, Somayeh and Mansour Koosha (2015) An Assessment of The Quality of Persian Translated Version of "White Fang" by Jack London Based on The Thematic Progression Analysis. International Journal of Educational. Vol.2, No.5: 118-127.

Wang, Bo (2014). Theme In Translation: A Systemic Functional Linguistic Perspective. International Journal of Comparative Literature \& Translation Studies. Vol. 2 No. 4

Wang, Fang(2014). The Application of Thematic Theory in Translation. Theory and Practice in Language Studies. Journal of Linguistics. Vol. 4, No. 4, pp. 778-785 